\title{
REFLEKSI LINGKUNGAN DALAM KUMPULAN CERPEN HIKAYAT BUJANG JILATANG KARYA AFRI MELDAM (TINJAUAN EKOKRITIK SASTRA)
}

\author{
Riri Novianti ${ }^{1^{*}}$, Wasana $^{2}$, Silvia Rosa ${ }^{3}$ \\ ririnovianti112@gmail.com* \\ Fakultas Ilmu Budaya Universitas Andalas, 1,2,3
}

\begin{abstract}
ABSTRAK
Artikel ini membahas gambaran lingkungan flora, fauna dan gambaran lingkungan sosial budaya yang terdapat dalam kumpulan cerpen Hikayat Bujang Jilatang. Tujuan dari penelitian ini adalah untuk menjelaskan keadaan lingkungan alam yang terdapat dalam kumpulan cerpen Hikayat Bujang Jilatang. Metode dan teknik penelitian yang digunakan dalam penelitian ini adalah metode ekokritik sastra. Ekokritik sastra adalah strategi pembacaan karya sastra yang bermuatan tentang aspek lingkungan (flora, fauna, dan budaya) yang terdapat dalam karya sastra. Teknik yang digunakan adalah menentukan cerpen yang mengandung pesan moral atau kritikan terhadap lingkungan dan menganalisis data-data yang ditemukan.

Hasil analisis data yang dilakukan pada penelitian ini dapat disimpulkan bahwa kumpulan cerpen Hikayat Bujang Jilatang merupakan refleksi lingkungan flora, fauna dan sosial budaya masyarakat. Pesan moral dan kritikan yang ada dalam kumpulan cerpen tersebut berperan untuk menjaga ekosistem alam. Kepercayaan rakyat yang ada dalam kumpulan cerpen Hikayat Bujang Jilatang merupakan kearifan lokal masyarakat yang hidup di desa untuk menjaga lingkungannya.
\end{abstract}

Kata kunci: Bujang Jilatang, Cerpen, Ekokritik, Lingkungan, Flora, Fauna.

\section{ENVIRONMENTAL REFLECTION IN HIKAYAT BUJANG JILATANG BY AFRI MELDAM (ECOCRITICISM VIEW)}

\begin{abstract}
This article discusses an overview of the flora, fauna, and socio-cultural environment in the short story collection Hikayat Bujang Jilatang. This study aims to explain the state of the natural environment contained in the short stories collection Hikayat Bujang Jilatang. The research methods and techniques used in this study are literary ecocritical methods. Literary ecocriticism is a strategy for reading literary works containing environmental aspects (flora, fauna, and culture) in literary works. The technique used is to determine short stories that contain moral messages or criticism of the environment and analyze the data found.

The results of data analysis carried out in this study can be concluded that the collection of short stories Hikayat Bujang Jilatang reflects the community's flora, fauna, and socio-cultural environment. The moral messages and criticisms in the short story collection play a role in protecting the natural ecosystem. The people's belief in the short story collection Hikayat Bujang Jilatang is the local wisdom of the people who live in the village to protect their environment.
\end{abstract}

Keywords: Bujang Jilatang, Short Story, Ecocriticism, Environment, Flora, Fauna.

Jurnal Elektronik WACANA ETNIK - Vol 9 No 1 2020, (40 - 55) p ISSN 2089-8746, e ISSN 2302-7142

Submit: Februari 2020. Diterima: Maret 2020. Publikasi: April 2020. 


\section{PENGANTAR}

Kumpulan cerpen Hikayat Bujang Jilatang ini, mengeksplorasi lingkungan sosial budaya, flora, dan fauna dalam lingkungan hidup pengarang. Setiap judul yang dipilih oleh pengarang merupakan cerminan lingkungan hidup masyarakatnya. Secara keseluruhan kumpulan cerpen ini berlatarkan Minangkabau. Seperti yang terdapat pada judul Salimang. Judul ini mengungkapkan bahwa ikan salimang telah punah, manusia yang serakah menggunakan racun untuk menangkap ikan tersebut. Sampai sekarang ikan salimang susah ditemukan di sungai. Masyarakat sebelumnya biasa menggunakan pukat untuk menangkap salimang, tentu hal ini tidak berdampak buruk bagi perkembangan ikan, anak -anaknya tetap bisa berkembang biak. Namun sebagian masyarakat menggunakan racun dan lain sebagainya hingga ikan tersebut terancam punah, dan air sungai ikut tercemar.

Keadaan lingkungan alam yang tercemar seperti sungai, ikan telah punah, pentingnya menjaga kelestarian lingkungan alam diungkapkan oleh pengarang dalam karyanya, seperti pada kumpulan cerpen Hikayat Bujang Jilatang. Bentuk kepedulian pengarang terhadap lingkungannya disalurkan melalui karyanya, untuk menyampaikan pesan dan amanat kepada khalayak.

Refleksi lingkungan dalam karya sastra dapat menggunakan perspektif ekokritik sastra. Endraswara (2016:48) menjelaskan bahwa ekokritik sastra adalah perspektif menafsirkan sastra dengan mempertimbangkan lingkungan. Endraswara (2016:49-50) memaknai ekokritik sastra sebagai studi tentang refleksi lingkungan dalam karya sastra.

Refleksi atau cerminan lingkungan dalam karya sastra dapat dilihat dari kumpulan cerpen Hikayat Bujang Jilatang yang ditulis oleh Afri Meldam. Kumpulan cerpen ini terdiri dari tujuh belas judul yaitu: Anjing Pemburu, Pemburu Kijang, Pohon Ayah, Rahasia Lubuk, Salimang, Bocah Laut, Cindaku, Darah Merah, Datuk Rajo Mudo, Dendang Malin Kundang, Di Balik Kabut Singgalang, Dua Bujang, Hikayat Bujang Jilatang, Ikan Bakar, Lubuk Tak Bernama, Ke Lisun Datuk Kembali, dan Pemburuan Terakhir.

Semua cerpen ini menjelaskan keadaan lingkungan alam pedesaan sebagai latar tempat dalam menyampaikan gagasan dan ide pengarang. Latar tempat yang dipilih pengarang memberikan gambaran kepada pembaca tentang lingkungan tempat tinggal pengarang itu sendiri. Setiap konflik yang dibangun oleh pengarang dilatarbelakangi oleh kehidupan dalam lingkungan masyarakat pedesaan. Sastra lisan dan mitos-mitos adalah suatu hal yang telah biasa bagi masyarakat yang menempati lingkungan tersebut, nilai sastra lisan dan mitos yang ada dalam masyarakat berfungsi untuk melestarikan dan melindungi flora, fauna dalam lingkungan alamnya. Hal ini tergambar dari setiap judul cerita yang diangkatkan. Pengarang menggiring tulisannya dengan tema-tema secara keseluruhan menggambarkan kedaerahan, kehidupan dalam lingkungan alam pedesaan. Lingkungan sosial budaya yang masih menjalankan ritualritual untuk kepentingan tertentu.

Kumpulan cerpen Hikayat Bujang Jilatang menarik diteliti menggunakan perspektif ekokritik sastra karena kumpulan cerpen ini berlatar daerah di Minangkabau. Setiap judul yang dipilih pengarang menggambarkan keadaan lingkungan alam di Minangkabau. Pengarang mencoba mengkritisi lingkungan sekitarnya dengan menyuguhkan mitos-mitos, nilai adat dan moral masyarakatnya. Kumpulan cerpen Hikayat Bujang Jilatang unik karena setiap judul

Jurnal Elektronik WACANA ETNIK - Vol 9 No 1 2020, (40 - 55) p ISSN 2089-8746, e ISSN 2302-7142 
bersumber dari lingkungan hidupnya. Tema yang diangkatkan merupakan refleksi dari keadaan lingkungan yang diamati pengarang. Hal inilah yang menarik untuk dikaji dari sudut pandang ekokritik sastra karena merupakan cara memaknai sastra yang berwawasan lingkungan.

\section{KERANGKA TEORI DAN METODE}

Ekokritik sastra adalah istilah yang berasal dari bahasa Inggris ecocriticism yang merupakan bentuk dari kata ecology dan kata criticism. Ekologi dapat diartikan sebagai kajian ilmiah tentang pola hubungan-hubungan tumbuhtumbuhan, hewan-hewan dan manusia terhadap satu sama lain dan terhadap lingkungan-lingkungannya. Kritik dapat di artikan sebagai bentuk dan ekspresi penilaian terhadap kualitas-kualitas baik atau buruk dari sesuatu. Secara sederhana ekokrtitik dapat dipahami sebagai kritik berwawasan lingkungan (Endraswara, 2016:36).

Harsono (2008: 33) menjelaskan bahwa ekokritik memiliki paradigma dasar bahwa setiap objek dapat dilihat dalam jaringan ekologis dan ekologi dapat dijadikan ilmu bantu dalam pendekatan kritik tersebut. Sudikan (2016: 9) menjelaskan bahwa ecocriticism bersifat interdisipliner dan multidisiplin. Di satu sisi, ecocriticism menggunakan teori sastra dan di satu sisi menggunakan teori ekologi. Dalam sudut pandang teori sastra, teori ecocriticism dapat dirunut dalam teori mimetik yang memiliki asumsi dasar bahwa karya sastra memiliki keterkaitan dengan kenyataan.

Endraswara (2016:39) mengungkapkan bahwa urgensi dari ekokritik sastra adalah mengungkap makna di balik karya-karya yang membeberkan lingkungan secara aneh. Untuk mengungkapkan hal tersebut dapat digunakan pendekatan mimesis. Edraswara (2016:41) menjelaskan bahwa teori ekokritik dapat dirunut dalam paradigma teori mimesis yang memiliki asumsi dasar bahwa kesusastraan memiliki keterkaitan dengan kenyataan.

Pendekatan mimesis (semesta) menempatkan karya sastra sebagai : (1) sebagai produk peniruan kenyataan yang di wujudkan secara dinamis, (2) representasi kenyataan semesta secara fiksional, (3) produk dinamis yang kenyataan di dalamnya tidak dapat di hadirkan dalam cakupan yang ideal, dan (4) produk imajinasi yang utama dengan kesadaran tertinggi atas kenyataan (Rokhmansyah, 2014: 9).

Endraswara (2016:49) mengasumsikan 3 dasar penelitian ekokritik sastra yaitu: (1) sastra lahir dari kondisi lingkungan tertentu, (2) sastra tidak mungkin lari dari lingkungan sekitar sastrawan, (3) sastra dilahirkan untuk memahami suasana lingkungannya. Dari pendapat tersebut terlihat bahwa ekokritik sastra tidak dapat dipisahkan dengan lingkungan. Endraswara (2016:54) menjelaskan bahwa teori pemahaman dalam konteks ekokritik sastra selaku membuka peluang makna. Makna boleh diraih tawar-menawar pemahaman.

Metode yang digunakan dalam penelitian ini adalah ekokritik sastra . Ekokritik sastra adalah untuk melihat kritik sastra yang memperhatikan aspek lingkungan. Adapun langkah yang digunakan dalam penelitian ini adalah membaca kumpulan cerpen Hikayat Bujang Jilatang berulang-ulang, menemukan permasalahan yang dibahas dalam setiap cerpen, dan menganalisis kumpulan cerpen Hikayat Bujang Jilatang dengan mendeskripsikan fakta-fakta yang ditemukan. 


\section{HASIL DAN PEMBAHASAN}

Kumpulan cerpen Hikayat Bujang Jilatang merupakan salah satu karya sastra yang mencerminkan keadaan lingkungan. Dari ke tujuh belas cerpen tersebut, pengarang mengungkapkan tentang lingkungan hidup di Minangkabau yaitu Sumpur Kudus. Dalam kumpulan cerpen tersebut juga mengandung pesan moral atau kritikan yang digambarkan melalui tindakan tokoh cerita terhadap lingkungannya. Terkait keadaan lingkungan sosial budaya masyarakat yang mayoritas petani, dan bergantung kepada alam. Lingkungan alam yang dikelilingi bukit dan hutan memberikan peluang kepada masyarakat untuk memanfaatkan hasil alam berupa flora dan fauna. Namun, keserakahan manusia terhadap hasil alam membuat flora, fauna dan biota sungai terancam, pesan moral yang diangkatkan pengarang dalam kumpulan cerpen Hikayat Bujang Jilatang adalah untuk menjaga lingkungan.

Perspektif ekokritik sastra pada penelitian ini merujuk pada pendapat Endraswara (2016:33) yang menyatakan bahwa ecocriticism bertujuan menunjukkan bagaimana karya sastra mempunyai kepedulian terhadap lingkungan dan berperan memecahkan masalah ekologi. Masalah ekologi yang tergambar dari kumpulan cerpen Hikayat Bujang Jilatang berupa pencemaran biota sungai, berburu fauna, dan lain sebagainya.

\section{Pelestarian Flora}

Kumpulan cerpen Hikayat Bujang Jilatang yang dapat dimaknai tentang pentingnya pelestarian flora terlihat dari cerpen Anjing Pemburu, Pemburu Kijang, Pohon Ayah, Rahasia Lubuk,Salimang, Dibalik Kabut Singgalang, Dua Bujang, dan Hikayat Bujang Jilatang. Terlihat gambaran lingkungan flora yang dapat dimanfaatkan oleh masyarakat untuk memenuhi kebutuhan hidup sehari-hari. Seperti pada cerpen Anjing Pemburu, tokoh Sutan yang memanfaatkan tumbuh-tumbuhan untuk mengobati luka, seperti kutipan berikut:

"lagi pula lukanya memang tak terlalu parah. Anjing itu menjulur-julurkan lidah ketika Sutan membasuh darah dilukanya, yang kemudian dibaluri dengan beberapa helai daun kaduduak yang sudah dilumat" (Meldam, 2015:4).

Dari kutipan di atas terlihat bahwa, tokoh Sutan memanfaatkan daun sebagai bahan pengobatan. Kehidupan di suatu kampung atau pedesaan sangat bergantung ke alam, hasil alam berupa tumbuh-tumbuhan dapat dimanfaatkan sebagai obat-obatan. Dari data di atas memberikan pengetahuan kepada pembaca bahwa, tumbuh-tumbuhan bisa dimanfaatkan sebagai obat tradisional yang aman untuk digunakan tanpa pengaruh zat kimia. Besarnya manfaat tumbuhan untuk kesehatan mengajarkan kepada pembaca betapa pentingnya melestarikan flora. Melalui pengobatan yang dilakukan oleh tokoh Sutan memberikan pengetahuan kepada pembaca agar bisa memanfaatkan tumbuhan untuk kesehatan, seperti ketika luka, tanpa harus menggunakan penanganan medis yang jauh dari daerah, karena memang kehidupan dilingkungan desa bisa memanfaatkan jenis tumbuhan misalnya seperti sikaduduak untuk pengobatan. Seperti yang telah dipraktikkan oleh tokoh Sutan.

Pada cerpen Pemburu Kijang tergambar kehidupan manusia yang bergantung kepada hasil alam, hasil tumbuhan yang dimanfaatkan berupa jengkol dan sayur daun labu, seperti pada kutipan berikut:

“..istrinya menghidangkan gulai jengkol dan sayur daun labu”(Meldam, 2015: 15) 
Dari kutipan di atas tergambar bahwa tumbuhan digunakan oleh manusia untuk dikonsumsi. Alam pedesaan menawarkan kepada manusia udara yang baik untuk bisa bercocok tanam, sehingga manusia bisa menikmati hasilnya untuk kebutuhan hidup sehari-hari. Pentingnya melestarikan flora dalam cerpen Pemburu Kijang terlihat dari cara tokoh dengan memenuhi kebutuhan hidup yang bergantung kepada hasil alam berupa tumbuh-tumbuhan. Di Minangkabau jengkol adalah tumbuhan yang dapat dimanfaatkan untuk memenuhi kebutuhan pangan. Jengkol bisa diolah menjadi kerupuk dan bisa dijual sebagai sumber ekonomi masyarakat. Tidak hanya kerupuk, jengkol itu sendiri memiliki nilai jual dengan harga yang cukup mahal.

Cerpen Pohon Ayah membahas masalah kasih sayang . Kasih sayang ayah terhadap pohon sama seperti sayangnya terhadap istri. Semenjak istrinya tiada pohon tersebut dirawat dengan penuh kasih sayang, hingga pohon tumbuh dan memberikan kenyamanan bagi ayah. Pohon tersebut menjadi tempat ternyaman ayah, bahkan ayah makan dan sholat di bawah pohon tersebut. Seperti pada kutipan berikut:

"Dulu ia balik ke rumah untuk makan, tapi sekarang, ketika waktu makan tiba, ia menyuruh Bi Yum membawa makanan untuknya ke sana. Ia makan di bangku kayu di bawah pohon itu. Sholat pun bahkan kini ia lakukan di sana. Hanya malam hari kami akan menemukannya ada di rumah" (Meldam, 2015:31).

Kasih sayang ayah terhadap pohon tidak sia-sia, bahkan pohon tersebut tumbuh membalas kasih sayang ayah dengan memberikan manfaat berupa dapat berlindung ketika panas. Kehadiran pohon bagi ayah sangat berarti, sama seperti kehadiran istrinya. Begitulah gambaran lingkungan yang sejuk yang memberikan kenyamanan pada mereka yang merawatnya. Lingkungan alam juga butuh dirawat dan dijaga sepeti kepedulian terhadap pohon dan hutan.

Kasih sayang ayah terhadap pohon digambarkan dengan jelas oleh pengarang. Kegiatan ayah bahkan bersikar di belakang rumah tempat pohon tersebut tumbuh. Bahkan kecintaan ayah terhadap pohonnya mendatangkan pikiran yang negatif bagi yang memandangi, hal ini tergambar dari kutipan berikut:

"Ayah asyik-masyuk dengan pohonnya. Ia seakan lebih nyaman berada di bawah pohonnya ketimbang di dalam rumah. Arzam, bahkan pernah memberitahuku kalau ia sering memergoki Ayah tengah mengobrol dengan pohonnya. "Ia bicara sendiri sambil tersenyum-senyum pada pohon itu," cerita Arzam. Belakangan, Arzam memberitahuku kalau tingkah ayah kian menjadi-jadi. Arzam tak jarang melihat Ayah sedang mencium dan memeluk pohon di belakang rumah" (Meldam,2015:31$32)$.

Pada kutipan di atas menggambarkan bahwa, kasih sayang ayah terhadap pohon tidak hanya sekadar merawatnya, namun cinta Ayah terhadap pohon terlihat seperti ia berhadapan dengan istrinya, bercakap-cakap bahkan sampai mencium dan memeluk pohon tersebut. Romantisme Ayah dengan alam memberikan makna bahwa, manusia tidak hanya romantis terhadap lawan jenis atau pasangan saja, bahkan dengan alam, manusia juga bisa bersikap romantis.

Tokoh Ayah yang digambarkan dalam cerpen tersebut mencerminkan bentuk pelestarian lingkungan alam berupa pohon. Seperti yang dipraktikkan oleh Ayah, merawat pohon sedari kecil. Ayah telah membuktikan bahwa lingkungan yang ditumbuhi pohon memberikan kesejukan dan manfaat bagi yang telah merawatnya. Melalui tokoh Hasbi tergambar bentuk perusakan terhadap lingkungan seperti pada kutipan berikut: 
"Ketika kabar duka dan pesan terakhir Ayah itu kusampaikan pada Bang Hasbi, ia dengan tegas mengatakan "Aku sibuk. Kau saja yang mengurus pemakaman Ayah. Biayanya biar nanti aku yang tanggung. Dan mengenai amanat itu, aku tidak setuju. Makamkan ayah di mana saja asal jangan di belakang rumah. tanah itu sangat strategis. Aku sudah punya proyek untuk lahan itu!" (Meldam, 2015:33).

Dari karakter yang melekat pada tokoh Hasbi tergambar bahwa, kebiasaan sebagian manusia yang tidak peduli dengan pohon. Tokoh Ayah adalah orang yang berusaha melestarikan flora, hal ini terlihat dari kebiasaan Ayah yang merawat pohon mulai dari kecil hingga pohon tumbuh menjadi tempat yang ternyaman buat Ayah. Pertentangan kedua tokoh ini menjelaskan tentang kehidupan manusia bahwa, di antara yang peduli dengan alam, ada juga yang bertindak sebaliknya. Dari tokoh Hasbi yang hadir dalam cerpen Pohon Ayah menggambarkan masalah pembalakan liar. Seperti yang terjadi di Sumbar pada tahun 2011 lalu tentang kondisi hutan Sumbar yang memprihatinkan. Hal ini berdampak bagi lingkungan itu sendiri dengan bencana banjir dan tanah longsor. Kerusakan hutan di Sumbar hampir terjadi merata di seluruh Kabupaten/Kota, dengan total kerusakan diperkirakan mencapai 60 persen dari 2,6 juta luas areal hutan yang ada. Kerusakan hutan terjadi akibat penebangan liar secara terus- menerus oleh pihak yang tidak bertanggung jawab. Berita tersebut dikutip dari (https://m.anataranews.com diakses pada 22 Oktober 2018).

Dari tindakan yang merusak lingkungan lahirlah peraturan tentang pelestarian tumbuhan seperti gerakan menanam satu batang pohon, hal ini seperti dilakukan oleh mahasiswa Unand angkatan 2015 yang sedang kuliah kerja nyata di setiap daerah lokasi KKN yang ditempati, itu semua bertujuan untuk melestarikan tumbuhan demi menjaga alam agar tetap terlindungi dan menghadirkan kenyamanan dalam lingkungan.

Cerpen Rahasia Lubuk juga menggambarkan tentang lingkungan flora. Dalam cerpen ini digambarkan tentang tumbuhan untuk dimanfaatkan sebagai makanan hewan peliharaan. Manusia hidup di alam dan memanfaatkan hasil alam untuk memenuhi kebutuhan hidup sehari-hari. Pada cerpen Rahasia Lubuk ini digambarkan tentang kebiasaan tokoh Gadih yang membawa ternaknya ke padang rumput, seperti pada kutipan berikut:

"Gadih tak lebih hanyalah seorang penggembala sapi yang menghabiskan hari-harinya di padang rumput" (Meldm, 2015:37).

Dari kutipan di atas terlihat bahwa, tokoh Gadih memanfaatkan tumbuhan seperti rumput untuk menghidupi ternaknya. Sudah sepantasnya manusia melestarikan tumbuhan untuk kelangsungan hidup hewan dan untuk melindungi menjaga lingkungan dari segala macam bencana. Dalam cerpen ini, pengarang menggambarkan tentang manfaat tumbuhan demi kelangsungan hidup manusia.

Cerpen Salimang juga menggambarkan tentang lingkungan flora yang dimanfaatkan oleh tokoh Marsiah seperti pada kutipan berikut:

"Marsiah perempuan tua itu baru saja menyisipkan beberapa lembar daun kanongan ke sela-sela atap rumbia yang menaungi gubuk mereka, mencoba menahan rembesan air hujan yang menetes masuk ke dapur" (Meldam, 2015: 45).

Dari kutipan di atas menggambarkan bahwa tumbuhan yang berfungsi untuk berlindung. Tumbuhan yang digunakan untuk atap pondok. Kehidupan tradisional di Minangkabau, seperti yang sering peneliti amati, apalagi hidup di pedalaman, semuanya tidak akan lepas dari kehidupan yang selalu bergantung ke alam. Tumbuhan yang dimanfaatkan oleh tokoh Marsiah menggambarkan tentang kehidupan di kampung yang masih tradisional. Atap rumah 
yang berasal dari rumbia dan ditambah dengan daun kanongan. Untuk zaman sekarang tumbuhan tersebut digunakan untuk membuat pondok di ladang.

Pentingnya melestarikan flora yang terdapat dalam cerpen Salimang yaitu terlihat dari tokoh cerita yang memanfaatkan tumbuhan untuk kebutuhan hidupnya. Pengarang cerpen mengajak pembaca untuk mengingat kesederhanaan hidup di suatu kampung yang masih memanfaatkan daun sebagai atap rumah untuk mereka berlindung.

Pesan moral yang tergambar dari kumpulan cerpen Hikayat Bujang Jilatang tentang pentingnya pelestarian flora juga tergambar dari cerpen Dibalik Kabut Singgalang. Seperti pada kutipan berikut:

"Naya langsung dibuat berdecak kagum oleh pemandangan yang sangat luar biasa yang terhampar di bawah sana. Persawahan yang menguning; rumah-rumah yang tampak begitu kecil; dan sungai Batang Sumpu yang terlihat tak ubahnya serupa seekor ular besar yang meliuk sepanjang mata memandang" (Meldam, 2015:99).

Kutipan di atas menggambarkan tentang keindahan alam yang dihiasi oleh tumbuhan seperti padi. Bentuk pelestarian flora yang terdapat dari kutipan tersebut yaitu tentang tumbuhan padi yang selalu jadi filosofi bagi masyarakat Minangkabau yaitunya "semakin berisi semakin merunduk" artinya setiap yang berilmu harusnya budi pekertinya semakin baik. Tumbuhan padi adalah kebutuhan pokok masyarakat Minangkabau. Latar tempat yang ada dalam cerpen tersebut adalah suatu desa yang jauh dari pusat kota. Tanaman seperti padi adalah mata pencarian masyarakat untuk memenuhi kebutuhan hidup sehari-hari. Alam pedesaan yang digambarkan oleh pengarang adalah lingkungan yang dihiasi oleh tanaman dan tumbuh-tumbuhan, yang mengajarkan kepada khalayak bahwa hidup di desa terasa damai dan nyaman dengan lingkungan penuh tumbuhan tanpa gangguan polusi udara.

Cerpen Dua Bujang menggambarkan tentang tumbuhan yang dimanfaatkan oleh tokoh cerita seperti pada kutipan berikut:

"Kala itu memang sedang musim ambacang. Dan, semua orang tentu tahu kalau Luthfi begitu doyan makan buah tersebut. Hingga ia pun tak segan-segan berebut buah ambacang yang jatuh dengan teman-temannya" (Meldam, 2015:108).

Tumbuhan ambacang hanya ada di desa, hampir mirip dengan mangga namun buah tersebut memiliki serabut. Dari kutipan di atas terlihat kehidupan di desa yang selalu memanfaatkan hasil alam berupa hasil tanaman baik di konsumsi. Perlunya melestarikan flora diisyaratkan oleh banyaknya manfaat yang diperoleh dari hasil tumbuhan. Sudah sewajarnya manusia kembali ke alam, dalam artian bahwa manusia harus peduli dengan alam lingkungan, terutama melestarikan tumbuhan demi pemenuhan kebutuhan pangan dan lain sebagainya. Firman Allah dalam Al-Quran surah Al-Baqarah ayat 62 menganjurkan manusia untuk "makan dan minumlah dari rezeki yang diberikan Allah, dan janganlah kamu melakukan kejahatan di bumi dengan berbuat kerusakan". Panutan hidup manusia telah melarang melakukan kerusakan di alam. Agar lingkungan alam terlindungi dan menghindari kerusakan alam, salah satu upaya yang dilakukan adalah dengan melestarikan tumbuhan.

Pada cerpen Hikayat Bujang Jilatang pengarang menggambarkan kebiasaan tokoh Zulfirman seperti tumbuhan yang berbahaya. Nilai kearifan ekologis yang terdapat dalam cerpen ini adalah alam tidak saja berfungsi untuk memenuhi kebutuhan hidup manusia. Namun dari alam manusia dapat belajar dan mengambil pelajaran. Dari latar cerpen Hikayat Bujang Jilatang menggambarkan tentang kehidupan masyarakat Sumpur Kudus. Peran 
lingkungan Sumpur kudus dalam cerpen ini mencerminkan bahwa masyarakat hidup di lingkungan yang masih dikelilingi oleh tumbuh-tumbuhan. Sehingga masyarakat selalu berpatokan kepada alam. Hal ini tergambar dari karakter Zulfirman yang berkelakuan sangat buruk. Semua orang merasa risih dengan perbuatan yang ia lakukan. Bentuk karakter yang ada pada Zulfirman sama seperti tumbuhan jilatang yang berdampak buruk bagi manusia yang menyentuhnya.

Cerpen Perburuan Terakhir menggambarkan lingkungan yang biasa di tempati oleh fauna. Konteks lingkungan flora dalam cerpen ini dapat dimaknai bahwa padang rumput adalah tempat fauna mencari makan. Lingkungan tempat fauna hidup, dan mestinya manusia menjaga lingkungan tersebut agar flora tetap hidup dengan baik dan populasi fauna tetap terlindungi. Lingkungan flora yang digambarkan dalam cerpen ini adalah sebagai berikut:

“..Jika tadi mereka berada di sebuah lembah yang diapit tebing karang penuh pakis, sekarang mereka berada di sebuah padang rumput yang maha luas. Tak seorang pun dari mereka pernah melihat padang rumput seluas itu" (Meldam, 2015: 160-161).

Dari kutipan di atas, lingkungan alam yang digambarkan memberi pesan kepada pembaca untuk menjaga lingkungan flora. Cerpen ini mengisahkan tentang perburuan. Di mana tokoh yang melakukan perburuan terjebak ke padang rumput. Karena telah melakukan pelanggaran terhadap alam yaitu menembak binatang yang baru pertama mengandung anaknya. Pesan yang dapat diambil dari cerpen Perburuan Terakhir terhadap pelestarian alam adalah keberadaan tokoh di lingkungan yang penuh rumput. Tempat yang belum pernah seorang pun mereka lihat. Hal ini menandakan bahwa lingkungan yang ditempati oleh tokoh dalam cerpen ini sudah tidak tumbuhan rumput yang terjaga. Ketika tersesat dalam perburuan, mereka menemukan padang rumput, karena memang di sanalah tempat fauna berkembang biak.

Pelestarian flora yang terdapat dalam kumpulan Cerpen Hikayat Bujang Jilatang terlihat dari tindakan tokoh utama yang selalu merawat alam, seperti pada tokoh Ayah. Perusakan lingkungan terlihat dari tokoh Hasbi yang melanggar amanat ayah, keinginan tokoh Hasbi untuk mendirikan proyek dekat tumbuhan pohon yang telah dirawat oleh ayah sedari kecil. Dari kumpulan cerpen tersebut terlihat manfaat tumbuhan bagi kehidupan manusia, ada yang memanfaatkan untuk obat-obatan, sebagai tempat berlindung atau ganti atap pondok dan untuk dikonsumsi. Dengan banyaknya manfaat yang ditawarkan oleh lingkungan flora, memberikan pesan kepada manusia untuk peduli dan melestarikan flora agar tetap terjaga dan manusia bisa memanfaatkannya dengan baik.

\section{Pelestarian Fauna}

Pada kumpulan cerpen Hikayat Bujang Jilatang yang membahas tentang lingkungan fauna terdiri dari beberapa cerpen di antaranya Anjing Pemburu, Pemburu Kijang, Rahasia Lubuk, Salimang, Bocah Laut, Darah Merah, Ikan Bakar, Lubuk Tak Bernama dan Perburuan Terakhir. Pembahasan di bab II telah menggambarkan tentang lingkungan fauna dalam kumpulan cerpen Hikayat Bujang Jilatang. Dari pembahasan tersebut, ada pesan moral yang disampaikan oleh pengarang melalui tokoh yang memerankan cerita. Pesan tersebut ditujukan kepada pembaca agar melestarikan fauna. Lingkungan fauna yang terdapat dalam cerpen tersebut berperan untuk menjelaskan kepada pembaca, tentang kehidupan sosial masyarakat yang selalu bergantung kepada alam. Seperti memburu rusa da 
menangkap ikan. Namun, cara yang dilakukan dalam menangkap rusa dan menangkap ikan menyebabkan populasinya terganggu bahkan terancam punah. melalui cerpen inilah pengarang mengkritik tindakan manusia yang tidak peduli dengan dampak buruk dari perbuatan yang merusak lingkungan. Hal ini akan dibahas dari pengelompokan cerpen yang menggambarkan fauna yang sama seperti pada pembahasan berikut.

Cerpen Anjing pemburu, Pemburu Kijang dan Perburuan terakhir . Dilihat dari gambaran cerita, lingkungan pedesaan yang masih asri dan masih dikelilingi hutan dijumpai fauna seperti rusa, kijang, dan lain sebagainya. Seperti pada kutipan berikut:

"Di sebuah persimpangan sungai, ia melihat jejak kaki kijang mengarah mengarah ke kanan. Ia tersenyum simpul, penuh harap, penuh debar. Kau tak akan bisa lari dariku, kijang. Ia tahu, di hutan di sebelah kanan yang menjadi hulu sungai itu, kijang itu tak akan berjalan melintasi bukit. Di sana ia hapal sekali, terdapat padang pakis yang luas, yang tentu menjadi tujuan sang kijang untuk mengisi perutnya selama satu-dua hari” (Meldam, 2015:14).

Dari kutipan di atas, menggambarkan lingkungan alam yang dilalui dan dihuni oleh fauna. Hutan, sungai, bukit adalah tempat sang fauna hidup. Masyarakat yang berada di desa, seperti yang tergambar pada kutipan di atas, sangat antusias mendapatkan fauna, tokoh dalam cerpen tersebut telah hafal dengan kehidupan fauna dan lokasi kehidupannya. Dari gambaran tersebut, pengarang menghadirkan kejadian yang aneh dilalui oleh tokoh cerita, tujuan kejadian tersebut agar fauna terlindungi. Berbagai latar belakang yang dialami oleh tokoh cerita. Seperti yang terdapat pada cerpen Anjing Pemburu. Alam tidak mendukung tokoh Sutan untuk melakukan perburuan, seperti pada kutipan berikut:

"Petang yang sial! Begitu Sutan mengingat hari sebelum senja kali itu. Betapa tidak, kala itu alam seolah tidak merestuinya untuk pergi berburu. Seharian memburu jejak kijang, ia seolah dikepung oleh serentetan kesialan yang membuatnya bertanya-tanya apakah ia sudah melanggar sumpah kepada hutan, semisal meludah di pertemuan dua sungai atau terkencing di dekat mata air" (Meldam, 2015:2).

Dari kutipan di atas terlihat bahwa, alam digambarkan seakan tidak merestui Sutan untuk pergi berburu. Bagi orang yang berburu, ternyata pantangan yang harus dituruti merupakan sumpah dari perjanjian manusia dengan alam agar sama-sama menjaga kelestariannya. Hal ini juga digambarkan dari kutipan di atas bahwa sumpah manusia dengan alam harus dipatuhi, berupa meludah di pertemuan dua sungai atau terkencing di dekat mata air. Tujuan dari sumpah yang digambarkan di atas adalah cara agar masyarakat melindungi alamnya. Dapat dimaknai bahwa mata air adalah sumber untuk penghidupan bagi masyarakat. Semua orang butuh air, jika air tersebut dikotori seperti diludahi, dikencingi, tentunya akan berimbas kepada masyarakat yang mengonsumsi air tersebut.

Kepercayaan masyarakat yang tercermin dalam ketiga cerpen tersebut adalah, mengekspos nilai-nilai penjagaan alam bagi masyarakat Minangkabau dari zaman dahulunya. Kepercayaan tersebut dapat menjadi pertimbangan bagi masyarakat agar tidak mudah melakukan perburuan yang menyebabkan populasi hewan jadi punah. Seorang pemburu akan melakukan perburuan setelah ia melakukan ritual, mematuhi larang, pantangan yang diyakini agar ia selamat. Dalam hal ini dapat dilihat dari masing-masing cerpen seperti pada cerpen Anjing Pemburu, yang tergambar dari kutipan berikut:

"Tapi ia tahu betul dengan segala pantangan yang selalu dipatuhi seorang pemburu. Ia tidak menyentuhkan parang dan senapan yang ia bawa ke tanah. Lagi pula, senja itu, sebelum masuk 
hutan ia telah mematahkan dua potong ranting di dua sisi jalan dan telah pula 'memandikan' Simumuik dengan salagho semak-semak kering yang berserakan di tanah sebagai petanda bahwa ia minta izin pada Ninik Lingkisau, pemelihara binatang di hutan" (Meldam, 2015:2).

Dari kutipan di atas dapat diartikan bahwa, untuk pergi berburu seorang pemburu harus meminta izin kepada orang yang mereka yakini sebagai penjaga hewan yang ada di hutan. Pemburu melakukan langkah-langkah untuk meminta izin kepada penjaga hutan yang mereka yakini, jika semua langkah-langkah tersebut mereka patuhi, mereka akan mendapatkan hewan buruan.

Fungsi alam yang digambarkan pengarang sangat beragam, ada yang memanfaatkan untuk berburu fauna, ada juga yang memanfaatkan tumbuhan dalam melengkapi persyaratan untuk melakukan perburuan, seperti memandikan Simumuik dengan semak-semak kering yang berserakan di tanah. Semak-semak kering digunakan sebagai persyaratan untuk meminta izin dalam berburu, digunakan untuk memandikan anjing yang ikut dalam berburu. Selain semak-semak kering, tumbuhan hidup juga digunakan sebagai obat untuk menyembuhkan luka yang ada pada tubuh anjing, seperti pada kutipan berikut:

"Lukanya memang tak terlalu parah. Anjing itu menjulur-julurkan lidah ketika Sutan membasuh darah di lukanya, yang kemudian dibaluri dengan beberapa helai daun kaduduak yang sudah dilumat" (Meldam, 2015:3-4).

Kepercayaan yang diyakini oleh masyarakat melalui tokoh cerita tersebut menggambarkan bahwa, masyarakat Minangkabau melindungi lingkungan alam, menjaga fauna dengan meyakini kejadian yang telah berlalu. Bagi masyarakat hal tersebut dapat dijadikan pedoman agar tidak melakukan perburuan. Endraswara (2016:27) menyatakan bahwa dalam masyarakat tradisional sistem kepercayaan terwujud dalam sikap percaya terhadap eksistensi alam dan manusia eksistensi roh dan kekuatan adikodrati, eksistensi jiwa, dan kekuatan adikodrati flora, fauna, situs dan benda pusaka.

Cerpen yang berjudul Pemburu Kijang, mengisahkan hal yang sama dengan cerpen Anjing Pemburu. Mereka yang telah mengikuti langkah-langkah untuk melakukan perburuan tetap gagal mendapatkan hewan buruannya. Seperti pada cerpen Pemburu Kijang, tokoh Sutan gagal mendapatkan hewan buruannya, meskipun doa-doa yang di ajarkan ayahnya telah ia baca agar perburuannya diizinkan oleh Niniak penjaga hutan. Akhirnya Sutan takut dengan anjing yang biasa ia bawa pergi berburu. Pada kesimpulannya Sutan, ayah dan anaknya yang terbiasa berburu, akhirnya menjadi hewan yang biasa ia buru. Kejadian tersebut merupakan sumpah yang mereka terima, seperti pada kutipan berikut:

"Inilah sumpah yang harus kita terima. Ikhlaskanlah semuanya," seekor kijang tua menenangkan Sutan..

“..Iya, Ayah,” ujar Sutan Pelan, lalu ia berlari menyambut kijang muda yang baru datang itu, yang tampak belum bisa menerima segala perubahan yang terjadi pada tubuhnya" (Meldam, 2015:9).

Pada kutipan di atas dapat memberikan gambaran bahwa, Sutan yang biasa memburu kijang berubah menjadi seperti hewan yang ia buru, hal ini sudah terjadi jauh sebelumnya, ayahnya juga menjadi kijang sampai pada generasi Sutan, anak Sutan yang mewarisi sifat Sutan yang biasa berburu juga berubah menjadi kijang. Kejadian yang tergambar dari cerpen tersebut merupakan pelajaran bagi masyarakat bahwa, tujuan dari kisah tersebut agar kebiasaan berburu hewan, seperti kijang dan sejenisnya menjadi hal yang ditakuti, dijadikan bahan pertimbangan bagi 
masyarakat yang ada dilingkungan tersebut agar kejadian aneh tidak menimpa diri mereka. Kejadian-kejadian yang terjadi sebelumnya dijadikan pembelajaran agar terjaga keamanan di lingkungan masyarakat yang dikelilingi bukit, hutan luas, agar tidak tersesat di hujan tersebut, agar hewan yang diburu tidak punah.

Dalam cerpen Perburuan Terakhir seperti yang telah di jelaskan sebelumnya, cerpen ini juga berkisah seputar perburuan, Angku Kotik sebagai tokoh utama dalam cerpen ini berkarakter keras kepala. Dalam perburuan itu, Angku Kotik dan kawan pemburunya seakan tidak diizinkan oleh alam untuk menembak hewan buruan, seperti yang terlihat dari kutipan berikut:

"Mendadak langit berubah menjadi kelam. Awan tebal bergumpal-gumpal menjadi selimut yang menutupi matahari. Angin seolah berhenti. Suara-suara hilang. Dan, saat itulah, samar-samar para pemburu mendengar suara entah apa dari dekat tebing tempat rusa itu terjebak, berbisik halus ke telinga mereka. Jangan bunuh rusa itu. Dia sedang mengandung anak pertamanya" (Meldam, 2015:155).

Meskipun sudah ada isyarat bagi mereka agar tidak menembak rusa yang mereka buru, Angku Kotik sebagai kepala rombongan tetap tidak sabar ingin mendapatkan rusa tersebut hingga benar-benar ia dapatkan. Namun, akhirnya mereka sadar bahwa rusa yang mereka buru adalah rusa keramat. Anak yang ada dalam perut rusa tersebut tetap hidup meskipun induknya telah dibantai. Seperti yang digambarkan pada kutipan berikut:

"Tapi, tiba-tiba sesuatu seolah bergerak di dalam perut rusa betina itu. Angku Kotik hampir saja terlonjak saking terkejutnya menyaksikan perut yang sudah dikuliti itu menggeliat..

“..Anaknya masih hidup!” Entah siapa yang meneriakkan kata-kata itu, yang lalau diiyakan oleh semua pemburu yang lain” (Meldam, 2015:158).

Kejadian demi kejadian telah mereka sadari bahwa alam tidak mengizinkan mereka untuk memburu rusa yang sedang mengandung. Pada akhirnya mereka terpisah dengan kepala rombongannya, bahkan mereka tiba di padang rumput yang terhampar hijau. Mereka tidak tahu sama sekali tempat itu. Dari kisah dalam cerpen ini tergambar bahwa, alam tidak memberi izin kepada pemburu untuk menaklukkan hewan buruannya. Peristiwa yang tidak diduga bakal terjadi apabila tidak mematuhi kodrat alam. Hewan seperti rusa yang dikisahkan dalam cerpen ini mengandung untuk pertama kalinya. Kalau hewan tersebut tetap diburu, tentunya populasi hewan tersebut terganggu, dan berakibat punah. Dalam cerpen ini juga tergambar dengan jelas latar lingkungannya, hewan seperti rusa memang hidup di hutan yang berlembah dan di sekitarnya ada tumbuhan seperti rumput, pakis. Karena memang rusa memakan rumput. Seperti pada kutipan berikut:

"Jika tadi mereka berada diapit tebing karang penuh pakis, sekarang mereka berada di sebuah padang rumput yang maha luas. Tak seorang pun dari mereka yang pernah melihat padang rumput seluas itu" (Meldam, 2015:160-161).

Mereka yang bersama-sama berburu, Angku Kotik sebagai kepala rombongan telah mengalami kegagalan dalam berburu. Kegagalan di sini di dasarkan pada kisah sebelumnya yang menggambarkan, bahwa mereka melihat anak rusa itu menari seakan membacakan ritual. Bahkan kabut menghalangi pandangan mereka sampai mereka tidak melihat teman sebelahnya. Dan akhirnya mereka terpisah dengan Angku Kotik. Mereka tidak mengetahui tempat keberadaan mereka yang sekarang. Mereka telah melihat hamparan rumput yang luas.

Makna dibalik kejadian aneh dalam cerpen ini, merupakan kepercayaan masyarakat yang direvitalisasi oleh pengarang untuk menunjukkan bahwa masyarakat zaman dahulu mempercayai mitos, dengan kejadian-kejadian yang 
aneh untuk menjaga fauna dan menjaga alam lingkungan. Dampak buruk dari berburu ditonjolkan oleh pengarang dengan kejadian yang dialami oleh tokoh utamanya. Selain itu, alam juga digambarkan tidak merestui perjalanan untuk berburu. Jika alam tidak dimanfaatkan dengan baik, maka alam juga memberikan yang tidak baik kepada yang memperlakukannya. Dapat disimpulkan bahwa, setiap keanehan yang dialami oleh tokoh cerita merupakan bentuk sanksi alam terhadap mereka yang memperlakukan alam secara tidak baik. Seperti contoh dalam cerpen tersebut, bahwa rusa yang akan diburu merupakan rusa yang baru pertama kali mengandung, jika tetap diburu tidak saja hewan tersebut yang mati, anaknya juga akan mati dan perkembangbiakan rusa selanjutnya ikut terganggu.

Cerpen Salimang, Bocah Laut, Ikan Bakar, dan Lubuk Tak Bernama menggambarkan tentang kehidupan di lingkungan yang selalu memanfaatkan hasil alam berupa ikan. Pada cerpen Salimang menggambarkan tentang kerinduan tokoh terhadap ikan salimang. Melalui cerpen ini pengarang mengkritik perbuatan manusia yang mengakibatkan ikan salimang terancam punah. seperti yang tergambar dari kutipan berikut:

"Seiring perkembangan zaman, kini, orang-orang tak lagi menggunakan jala atau pukat untuk menangkap ikan. Orang-orang sudah dimanjakan oleh teknologi. Ikan-ikan ditangkap dengan menggunakan aliran listrik atau dengan menebar racun ke dalam sungai. Maka, dalam sekejap saja, ikan-ikan akan menggelepar, lalu terapung dengan tubuh beku. Hingga, dari hari ke hari, ikan pun menjadi semakin sukar didapatkan" (Meldam, 2015:48-49).

Dari kutipan di atas menggambarkan tentang kehidupan di zaman yang sudah maju, di mana masyarakat menggunakan teknologi berupa aliran listrik untuk menangkap ikan. Hal tersebut berdampak buruk bagi perkembangan ikan dan masyarakat tidak dapat mengonsumsinya. Perbedaan cara menangkap ikan yang tergambar dari kutipan di atas dapat menjadi pertimbangan untuk khalayak agar menangkap ikan dengan cara tradisional, hal tersebut tidak merusak populasi ikan.

Dari kebiasaan buruk yang dilakukan dalam menangkap ikan, masyarakat yang peduli dengan lingkungannya berupaya mengatasi perbuatan tersebut dengan membuat kesepakatan masing-masing daerah. Masyarakat berupaya untuk melestarikan ikan dengan kebijakan di daerah masing-masing seperti ikan larangan. Tujuan dari ikan larangan yang berkembang dalam masyarakat adalah, agar ikan tidak punah, selain itu tidak hanya manusia yang serakah saja yang bisa menikmati ikan, namun hasil dari ikan larangan bisa digunakan untuk membangun nagari. Biasanya di masing-masing daerah membuat peraturan tentang ikan larangan dengan melarang masyarakat menangkap ikan selama dua tahun. Jika ketahuan menangkap ikan maka diberikan sanksi sesuai aturan yang telah disepakati sebelumnya. Seperti di lingkungan peneliti, acara penangkapan ikan larangan akan dibuka satu kali dalam dua tahun, acara tersebut berlangsung setelah hari raya Idul Fitri.

Bentuk penangkapan ikan pada data di atas yang mengakibatkan ikan punah adalah perbuatan yang merusak ekosistem sungai. Pengarang melalui tokoh Angah mengungkapkan betapa rindunya mereka memakan ikan yang ditangkap dengan pukat atau secara tradisional. Namun hal tersebut sudah menjadi kenangan karena ikan salimang telah punah akibat manusia yang serakah menangkapnya dengan aliran listrik dan racun. Bentuk kerinduan tokoh Angah terhadap ikan salimang adalah bentuk kerinduan masyarakat yang digambarkan oleh pengarang melalui karyanya. 
Penangkapan ikan telah ada aturannya, setiap yang menangkap ikan harus mengikuti aturan yang telah ditetapkan. Para nelayan harusnya menangkap ikan dengan peralatan yang dibolehkan tanpa merusak perkembangbiakan ikan. Pada cerpen Salimang, manusia yang tidak peduli dengan ekosistem sungai, mereka menggunakan racun dan aliran listrik untuk menangkap ikan. Hal tersebut membuat ikan punah. Aturan dalam menangkap ikan sebenarnya telah diketahui oleh semua orang jika kembali kepada pedoman hidup manusia, yang melarang berbuat kerusakan di muka bumi. Namun, keserakahan terhadap hasil alam membuat manusia lupa memikirkan hasil alam di hari esok.

Pada cerpen Bocah Laut berkisah tentang tokoh Liun yang putus sekolah demi ibunya dan bekerja menarik pukat di laut. Peran lingkungan yang terdapat dalam cerpen ini menggambarkan tentang kehidupan sosial masyarakat yang memanfaatkan hasil alam seperti ikan di laut untuk memenuhi kebutuhan hidup sehari-hari, bahkan tokoh Liun yang berhenti sekolah memanfaatkan hasil laut dengan cara menarik pukat. Hal ini dapat dilihat dari kutipan berikut:

"Tak lama, pukat lunas ditarik ke pantai. Orang-orang datang berkerumun. Liun berusaha menyelinap di antara tubuh-tubuh amis penarik pukat dan toke-toke pengumpul ikan. Hasil tangkapan mereka tak seberapa. Tak sampai setengah baskom. Liun hanya memperoleh tiga ekor ikan bawal kecil dan uang lima ribu rupiah sebagai upah" (Meldam, 2015: 58-59).

Pesan kelestarian terhadap ikan pada cerpen Bocah Laut ini adalah kesadaran masyarakat terhadap hasil alam. Hal ini terlihat dari kehidupan sosial masyarakat yang bekerja sebagai nelayan. Masyarakat yang hidup di pesisir dapat memanfaatkan hasil alam berupa menangkap ikan. Pada cerpen ini digambarkan bahwa Liun bekerja sebagai penarik pukat yang telah dibentangkan oleh pemiliknya. Hasil tangkapan dari menarik pukat dapat digunakan untuk memenuhi kebutuhan hidup sehari-hari.

Cerpen Ikan Bakar mengisahkan tentang masa lalu tokoh utama yaitu Laki-laki Tua. Laki-laki Tua bermimpi makan ikan bakar yang dipanggang dengan bara tempurung kelapa. Mimpi tersebut mengingatkan tentang kisahnya bersama keluarga yang terbiasa menangkap ikan dan menikmatinya bersama-sama. Istri Laki-laki Tua sangat pandai dalam membakar ikan sehingga semua keluarganya suka. Pesan moral yang dapat diambil dalam cerpen ini terhadap pelestarian fauna yaitu pengarang menggambarkan melalui tokoh utama tentang kehidupan sosial masyarakat yang bergantung kepada hasil alam berupa ikan. Di dalam cerpen tersebut digambarkan bahwa tokoh utama terbiasa menangkap ikan, dan ikan yang ditangkap pun tidak dibatasi besar kecil, bertelur atau tidaknya. Pada cerpen ini, tokoh utama menangkap semua jenis ikan yang ada di sungai yang ada di desa Sumpur Kudus, karena memang lingkungan di sana sangat mendukung kehidupan masyarakat untuk bergantung kepada hasil alam.

Pada cerpen Lubuk Tak Bernama menceritakan tentang tokoh utama yang memburu ikan sampai ke lubuk yang menelan nyawanya. Karani adalah tokoh utama cerpen ini yang terbiasa menangkap ikan dengan jala. Kejadian aneh yang diceritakan pengarang dapat dimaknai bahwa, lubuk yang selalu menjadi legenda bagi masyarakat untuk berhati-hati dalam memanfaatkan hasil alam. Di mana lubuk tersebut sangat ditakuti oleh semua orang, sudah menjadi semacam sastra lisan yang berkembang bagi masyarakat Sumpur Kudus agar berpedoman kepada cerita yang pernah tersebar di masyarakat. Dari kejadian aneh yang dilalui oleh tokoh Karani memberikan pesan ekologis kepada pembaca mengenai lingkungan yang harus dijaga. Pesan ini terlihat dari kutipan berikut: 
"Hanya beberapa kecipak air, Karani sudah sampai di ekor lubuk yang ia tuju, sebuah lubuk tak bernama. Pusaran air di tengah lubuk tampak meliuk-liuk memutar segala dedaunan dan ranting yang hanyut ke sana; membenamkan sampah-sampah itu ke dasar lubuk berwarna kehitaman. Seekor burung udang sesekali melintas di atas permukaan lubuk, menyambar ikan-ikan kecil yang berenang sedikit mengapung" (Meldam, 2015: 139).

Lubuk yang digambarkan dari kutipan di atas menjelaskan tentang lingkungan sungai yang kotor yang dipenuhi oleh sampah dan berwarna hitam. Kepercayaan rakyat terhadap lubuk tersebut didukung oleh keadaan lubuk yang tidak memungkinkan masyarakat untuk menangkap ikan ke lingkungan tersebut. Pesan ekologis yang bisa diambil dalam cerpen ini tidak hanya melestarikan ikan, namun juga mengisyaratkan untuk menjaga lingkungan sungai agar tidak tercemar dengan sampah yang dibuang oleh masyarakat, hal tersebut berdampak buruk bagi manusia itu sendiri. contohnya seperti kejadian pada tokoh Karani yang tidak bisa mendapatkan ikan yang besar di lubuk tersebut.

\section{Simbiosis Mutualisme Manusia dengan Flora dan Fauna}

Dari kumpulan cerpen Hikayat Bujang Jilatang juga menggambarkan tentang simbiosis manusia dengan tumbuhan dan hewan. Simbiosis mutualisme manusia dengan tumbuhan terlihat dari kehidupan sosial masyarakat yang hidup dengan hasil alam, karena manusia tidak bisa lepas dari lingkungan alam. Tumbuh seperti sayur, padi dan pohon dimanfaatkan oleh manusia untuk memenuhi kebutuhan hidupnya, selain itu, tumbuhan seperti pohon juga memberikan tempat yang nyaman untuk melindungi manusia dari sinar matahari langsung. Seperti yang telah dibahas sebelumnya tentang beragam manfaat tumbuhan bagi manusia, seperti untuk obat-obatan, untuk dijadikan atap pondok, untuk dikonsumsi seperti tumbuhan padi yang diolah menjadi beras dan nasi. Semua manfaat yang ditawarkan tumbuhan tidak akan lepas dari cara bagaimana manusia merawat dan menjaga tumbuhan. Seperti yang telah dipraktikkan oleh tokoh Ayah dalam cerpen Pohon Ayah. Perawatan yang Ayah lakukan memberikan manfaat untuk kenyamanan ayah, bisa menjadi tempat berteduh, dan lain sebagainya.

Hubungan manusia dengan hewan terlihat pada cerpen Anjing Pemburu, Pemburu Kijang dan Perburuan Terakhir. Ketiga cerpen ini menggambarkan bahwa hubungan tokoh Sutan dengan anjing sangat akrab. Hubungan ini dapat dilihat ketika tokoh pergi berburu. Mereka dibantu oleh anjingnya untuk menemukan jejak kijang, rusa dan lain sebagainya. Kebaikan anjing terhadap tuannya tergantung bagaimana kebaikan tuannya itu sendiri. Tokoh cerita dalam cerpen Anjing Pemburu digambarkan pemarah, namun tetap setia kepada anjingnya. Ketika anjingnya terluka Sutan tetap merawat anjingnya seperti yang terlihat dari kutipan berikut:

"Lukanya memang tak terlalu parah. Anjing itu menjulur-julurkan lidah ketika Sutan membasuh darah di lukanya, yang kemudian dibaluri dengan beberapa helai daun kaduduak yang sudah dilumat. Sutan mengurut tungkai kaki anjingnya lantas menyuruhnya berdiri untuk minum ke sungai" (Meldam, 2015:3-4).

Dari kutipan di atas terlihat hubungan Sutan dengan anjingnya. Bagi mereka yang sudah terbiasa mengurusi anjingnya, mereka akan mengerti kebutuhan anjing tersebut. Begitu juga sebaliknya, meskipun anjing tidak mampu bicara, ketika tuannya bicara dengan bahasa tuannya, anjingnya akan patuh bahkan seolah paham dan mengerti dengan apa yang sedang tuannya ucapkan, hal ini terlihat dari dialog tokoh Sutan dengan Anjingnya berikut: 
“Apa kau masih kuat untuk berburu?” ia bertanya sambil mengelus-elus tubuh anjing berwarna keemasan itu. Simumuik memejamkan mata dan menyalak kecil beberapa kali, seakan ingin mengatakan pada tuannya bahwa ia sangat kuat untuk memburu kijang itu sampai dapat" (Meldam, 2015:4).

Pada cerpen Pemburu Kijang hubungan manusia dengan hewan peliharaannya tergambar dengan jelas. Bagi seorang pemburu, kebutuhan dalam melakukan perburuan adalah memiliki seekor anjing. Perjalanan dalam berburu akan dituntun oleh anjing yang telah terlatih. Merawat anjing menjadi suatu kepentingan sama seperti merawat diri sendiri. Semua kebaikan yang dilakukan oleh tuannya akan dibalas oleh anjing seperti membantu menunjukkan arah perjalanan binatang yang akan diburu. Hubungan manusia dengan hewan tergambar sebagai berikut:

"Ia menyorongkan mangkok makanan itu ke hadapan Somuik sambil mengelus-elus kepala anjing itu dengan penuh kasih sayang. Kau harus makan banyak, karena besok kita akan berburu kijang jantan yang gesit. Kau harus makan banyak biar kita bisa menangkap kijang jantan itu" (Meldam, 2015:14).

Dari kutipan di atas dapat dimaknai bahwa, kebaikan yang dilakukan oleh seseorang terhadap seekor anjing tidak akan terjadi begitu saja melainkan ada harapan dibalik semua itu. Hubungan manusia dengan hewan peliharaannya yang tergambar dari kutipan di atas menjelaskan bahwa, kasih sayang seseorang terhadap hewannya. Namun kasih sayang ini dilakukan dengan harapan hewan tersebut juga akan memberikan hal yang sama kepada tuannya berupa bantuan dalam menangkap binatang buruan. Dalam hal ini tergambar dari kutipan berikut:

"Pagi sekali, Sutan dan Somuik mulai berjalan menuju hutan di ujung ladang. Somuik tampak girang, mengibaskan ekornya lebih sering, dan sesekali menjilati kaki tuannya dengan tulus. Meski tidak muda lagi, semangat yang dimiliki Somuik tetap membuat Sutan kagum. Sudah berpuluh binatang yang ia buru bersama Somuik, dan Sutan tak pernah dibuat kecewa oleh anjingnya itu" (Meldam, 2015:15).

Dari kutipan di atas dapat dimaknai bahwa, hubungan antara Sutan dengan anjingnya Somuik terlihat sangat baik. Kebaikan yang dilakukan oleh Sutan terhadap anjingnya mendapatkan balasan yang setimpal, seperti mendapatkan hewan buruan yang dilakukan sebelumnya.

Cerpen Perburuan Terakhir juga menggambarkan hubungan manusia dengan hewan peliharaannya. Pada cerpen ini digambarkan bahwa dalam perburuan tidak lepas dari bantuan anjing. Kasih sayang yang dilakukan oleh pemburu, mengharapkan balasan dari hewan peliharaannya (anjing) untuk membantu dalam perburuan.

Dari ketiga cerpen Anjing Pemburu, Pemburu Kijang dan Perburuan Terakhir dapat dimaknai bahwa manusia memiliki hubungan timbal balik dengan hewan, dalam hal ini hubungan dengan hewan peliharaan. Kasih sayang dalam memelihara hewan mendapatkan imbalan dari hewan yang dipelihara. Imbalan yang diberikan seperti dalam perburuan. Seekor anjing akan menuntun tuannya dalam menemukan jejak hewan yang diburu.

\section{PENUTUP}

Kumpulan cerpen Hikayat Bujang Jilatang merupakan refleksi lingkungan yang dituliskan oleh pengarang dengan penuh imajinasi. Kepercayaan rakyat yang hidup dalam lingkungan masyarakat berfungsi untuk melindungi lingkungan alam bertujuan untuk melestarikan flora dan fauna. Lingkungan alam pedesaan yang masih kaya dengan hasil alam dimanfaatkan oleh manusia untuk memenuhi kebutuhan hidupnya. Pesan moral yang disampaikan 
pengarang melalui cerpennya mengajak pembaca untuk melestarikan flora dan fauna. Kejadian aneh dan kepercayaan rakyat yang digambarkan oleh pengarang merupakan bentuk revitalisasi dari kearifan lokal masyarakat yang hidup di desa bertujuan untuk menjaga lingkungan alamnya.

\section{REFERENSI}

Candra, A. A. 2017. "Ekokritik Dalam Cerpen Indonesia Mutakhir" dalam journal unesa ac.id. diakses pada tanggal 3 April 2019.

Dewi, Novita. 2015. "Manusia dan Lingkungan Dalam Cerpen Indonesia Kontemporer Analisis Cerpen Pilihan Kompas" dalam journal uny.ac.id . diakses pada tanggal 3 April 2019.

Endraswara, Suwardi. (2016). Metodologi Penelitian Ekologi Sastra Konsep, Langkah, dan Penerapan. Yogyakarta: CAPS.

Endraswara, Suwardi. (2011). Metodologi Penelitian Sastra. Yogyakarta: CAPS.

Endraswara, Suwardi. (2016). Sastra Ekologis Teori dan Praktik Pengkajian. Yogykarta: CAPS.

Febrina, Ria. (2015). "Artifisialitas Tokoh dan Bahasan Artifisial Afri Meldam" dalam sasindo-unand.blogspot.com. diakses pada 10 April 2019.

Harsono, Siswo. (2008). "Ekokritik: Kritik Sastra Berwawasan Lingkungan" dalam media.neliti.com. diakses pada 20 November 2019.

Meldam, Afri. (2015). Hikayat Bujang Jilatang. Yogyakarta: CV. Alif Gemilang Pressindo.

Mubarok, Zaky. (2017) "Kajian Ekokritik Pada Naskah Drama Kisah Perjuangan Suku Naga Karya Rendra" dalam openjurnal.unpam.ac.id. diakses pada 20 November 2019.

Navis, A.A. (1984). Alam Terkembang Jadi Guru. Jakarta: PT Pustaka Grafitipers.

Nurgiantoro, Burhan. (1995). Teori Pengkajian Fiksi. Yogyakarta: Gajah Mada University Press.

Rokhmansyah, Alfian. (2014). Studi dan Pengkajian Sastra Perkenalan Awal Terhadap Ilmu Sastra. Semarang: Graha Ilmu.

Stanton, Robert. (2007). Teori Fiksi. Yogyakarta:Pustaka Pelajar.

Sudikan, Setya. Edy. (2016). Ekologi Sastra. Lamongan: CV. Pustaka Ilalang Group.

Susanti, Sastri. (2016). "Kemanusiaan dan Kepedulian Lingkungan dalam Sepuluh Cerpen Eka Budianto". Dalam S. Endraswara, Sastra Ekologis Teori dan Praktik Pengkajian (hal. 190-228). Yogyakrta: CAPS.

Uniawati. (2014). " Nelayan di Laut Utara: Sebuah Kajian Ekokritik". dalam ojs.badanbahasa.kemdikbud.go.id. diakses pada 20 November 2019.

Yazid, Derizon. 2011. "Kondisi Hutan Sumbar Sangat Memperihatinkan" dalam https://m.antaranews.com/berita/253. Diakses pada tanggal 22 Oktober 2019. 